\title{
BCG Vaccine-Induced Trained Immunity and COVID- 19: Protective or Bystander?
}

This article was published in the following Dove Press journal:

Infection and Drug Resistance

\begin{abstract}
Gopala Koneru'
Gaber El-Saber Batiha ${ }^{2}$

Abdelazeem M Algammal (iD ${ }^{3}$

Mahmoud Mabrok ${ }^{4,5}$

Sara Magdy ${ }^{6}$

Shrouk Sayed ${ }^{6}$

Mai E AbuElmagd ${ }^{6}$

Reham Elnemr ${ }^{6}$

Mahmoud M Saad ${ }^{6}$

Noura H Abd Ellah ${ }^{7}$

Amal Hosni ${ }^{8}$

Khalid Muhammad iD ${ }^{9, *}$

Helal F Hetta (iD) ${ }^{10,11, *}$

'Department of Medicine, Division of Gastroenterology and Hepatology, Rutger New Jersey Medical School, Rutgers University, New Brunswick, NJ, 07I03, USA; ${ }^{2}$ Department of Pharmacology and Therapeutics, Faculty of Veterinary Medicines, Damanhour University,

Damanhur, 225I I, Egypt; ${ }^{3}$ Department of

Bacteriology, Immunology, and Mycology,

Faculty of Veterinary Medicine, Suez Canal

University, Ismailia, 4I522, Egypt; ${ }^{4}$ Department

of Fish Diseases and Management, Faculty of

Veterinary Medicine, Suez Canal University,

Ismailia, 4I522, Egypt; ${ }^{5}$ Fish Infectious Diseases

Research Unit (FID RU), Department of

Veterinary Microbiology, Faculty of Veterinary

Science, Chulalongkorn University, Bangkok,

10330, Thailand; ${ }^{6}$ Faculty of Medicine, Assiut

University, Assiut, 71515, Egypt; ${ }^{7}$ Department

of Pharmaceutics, Faculty of Pharmacy, Assiut

University, Assiut, 71526, Egypt; ${ }^{8}$ Department

of Clinical Pathology, Faculty of Medicine,

Assiut University, Assiut, Egypt; ${ }^{9}$ Department

of Biology, College of Science, United Arab

Emirates University, Al Ain, United Arab

Emirates; ${ }^{10}$ Department of Medical

Microbiology and Immunology, Faculty of

Medicine, Assiut University, Assiut, Egypt;

"Department of Internal Medicine, University

of Cincinnati College of Medicine, Cincinnati,

$\mathrm{OH}, 45267$, USA
\end{abstract}

*These authors contributed equally to this work

Correspondence: Khalid Muhammad; Helal F Hetta

Email k.muhammad@uaeu.ac.ae;

helalhetta@aun.edu.eg
Abstract: In late 2019, a new virulent coronavirus (CoV) emerged in Wuhan, China and was named as severe acute respiratory syndrome coronavirus-2 (SARS-CoV-2). This virus spread rapidly, causing the coronavirus disease-2019 (COVID-19) pandemic. Bacillus Calmette-Guérin (BCG) is a live attenuated tuberculosis (TB) vaccine, associated with induction of non-specific cross-protection against unrelated infections. This protection is a memory-like response in innate immune cells (trained immunity), which is caused by epigenetic reprogramming via histone modification in the regulatory elements of specific genes in monocytes. COVID-19 related epidemiological studies showed an inverse relationship between national BCG vaccination policies and COVID-19 incidence and death, suggesting that BCG may induce trained immunity that could confer some protection against SARS-CoV-2. As this pandemic has put most of Earth's population under quarantine, repurposing of the old, well-characterized BCG may ensure some protection against COVID-19. This review focuses on BCG-related cross-protection and acquisition of trained immunity, as well as the correlation between BCG vaccination and COVID-19 incidence and mortality.

Keywords: COVID-19, BCG vaccine, coronavirus, trained immunity, tuberculosis

\section{Introduction}

Coronaviruses (CoVs) have been known since the 1930s and they cause a wide variety of diseases in both animals and humans. Since the 1960s, seven human alpha- and beta-CoVs were identified. However, life-threatening pathogenic strains started to spill over from animals into humans in late 2002, causing severe respiratory disorders. ${ }^{1-4}$ These strains are beta-CoVs such as severe acute respiratory syndrome coronavirus (SARS-CoV), which emerged in 2002/2003 in China, and ten years later, Middle East respiratory syndrome coronavirus (MERS-CoV) emerged in the Middle East region. ${ }^{1-3,5-7}$ In late 2019, a new coronavirus strain emerged in Wuhan/China and in February 2020, it was named severe acute respiratory syndrome coronavirus-2 (SARS-CoV-2) due to the phylogenetic similarity (79.5\%) with SARS-CoV. ${ }^{8}$ This virus spread rapidly between and within other countries, causing coronavirus disease-2019 (COVID-19) and created a public health emergency. In March 2020, it was declared by the World Health Organization (WHO) that the COVID-19 outbreak was a global pandemic. ${ }^{9}$ As of February 14, 2021, the WHO states that this global COVID-19 outbreak has resulted in around 108,246,992 confirmed cases and over 2,386,717 deaths worldwide. ${ }^{10}$ To rapidly contain this outbreak, the genome sequence of SARSCoV-2 was revealed within weeks of the viral emergence. Parallel to several 
repositioned antiviral drugs (such as remdesivir),${ }^{11-28}$ several promising vaccine candidates (such as $\mathrm{Ad} 5-\mathrm{nCoV},{ }^{29}$ mRNA- $1273,{ }^{30}$ PiCoVacc and INO- $4800^{31}$ ) are being clinically studied. Currently, there are available vaccines for COVID-19 as Pfizer-BioNTech COVID-19 Vaccine, Moderna COVID-19 vaccine, Janssen (Johnson \& Johnson) COVID-19 vaccine and AstraZeneca/Oxford COVID-19 vaccine. ${ }^{32}$

Considering the urgent need to strengthen the immune response of populations and to face the rapidly spreading COVID-19 pandemic, ${ }^{33,34}$ induction of trained immunity could be a potential protective approach against infections until developing effective therapy. ${ }^{35}$ Trained immunity means a prolonged hyperactivation of the innate immune system (monocytes, macrophages, and natural killer (NK) cells) to unrelated infections. Bacillus Calmette-Guérin (BCG) vaccine, which has been used for decades against tuberculosis (TB), is one of the most prominent examples for induction of trained immunity. BCG shows decreased susceptibility to unrelated infectious agents, especially respiratory tract infections such as influenza A virus, respiratory syncytial virus (RSV) and herpes simplex virus type 2 (HSV2). ${ }^{36-41}$ Interestingly, nations with mandatory BCG vaccines were shown to correlate with low number of COVID-19 confirmed cases as well as reduced mortality. ${ }^{42-46}$ This inverse correlation may be attributed to the long-term boosting of innate immune mechanisms (BCG-induced trained immunity). However, comparison between countries where the BCG vaccine is used with countries where it is not used can be affected by different factors including demographic characteristics, socioeconomic status, COVID-19 testing rate, stage of the pandemic in each country, clinical care, infection prevention and control policies. Additionally, climate and urban differences between countries affect COVID-19 confirmed cases. ${ }^{47,48}$ Moreover, being still in the midst of the COVID-19 pandemic and with cases still increasing even in countries with BCG vaccines, it is considered too early to have immature conclusions based only on ecological studies. Therefore, to draw conclusions regarding BCG vaccine and COVID-19, clinical studies are needed to support the ecological studies. The WHO declared that there is no evidence that $\mathrm{BCG}$ vaccine can protect against COVID-19 and they are still waiting for clinical trials outcomes. ${ }^{49}$ A collection of published articles about $\mathrm{CoVs}$ and BCG vaccination are used in the review. This review focuses on BCG-induced cross-protection and acquisition of trained immunity, as well as the correlation between this BCG vaccine-induced trained immunity on COVID-19.

\section{Coronaviruses, Symptoms and Prognosis of COVID- 19}

Coronaviruses (CoVs) are a group of viruses that infect humans and animals. There are four CoVs (229E, NL63, OC43 and HKU1), which are characterized with low pathogenicity. The more pathogenic CoVs causing fatal diseases are SARS-CoV, which emerged in China and MERS-CoV, which emerged in the Middle East region. ${ }^{1-3,5-7,50,51}$ Currently, we live a global crisis due to SARS-CoV-2..$^{50,52-54}$ On December 2019, the first COVID-19 cases were documented by the WHO in the seafood market in Wuhan city, Hubei province, China. ${ }^{8}$ Within a month, the virus spread from Wuhan to other areas within and outside China.

Transmission from person to person frequently occurs with close contact. ${ }^{55}$ Initially, transmission occurs through the respiratory droplets produced by sneezing, coughing or even talking. Contaminated droplets settle in various parts of the body, such as nose, mouth, lungs and eyes. ${ }^{56,57}$ Additionally, the virus can spread by touching contaminated surfaces or objects. ${ }^{56,58}$ SARS-CoV-2 can infect the gastrointestinal tract and it was isolated from fecal swabs. ${ }^{26}$ Therefore, the virus can spread via the fecaloral route. ${ }^{26,59,60}$ Airborne transmission may be possible in specific conditions.

COVID-19 symptoms vary among individuals, from asymptomatic infection to serious respiratory failure. ${ }^{61}$ Fever, cough, fatigue, slight dyspnoea, sore throat, headache and conjunctivitis are common symptoms of the disease. ${ }^{62-64}$ Gastrointestinal involvement, with diarrhoea, nausea and vomiting, was reported in a lower percentage of cases. Li et al. ${ }^{65}$ hypothesized that SARS-CoV-2 could have neuroinvasive potential, since viral entry into the central nervous system may contribute in some patients to development of respiratory failure. The reported hyposmia and hypogeusia experienced by individuals with COVID-19 could also indicate a potential neurotropism of this virus. ${ }^{66}$ The neuroinvasive capacity of SARS-CoV -2 remains poorly understood. ${ }^{67}$ Mortality due to COVID19 appears to be lower than that of SARS-CoV $(10 \%)$ and MERS-CoV (35\%). ${ }^{58,68}$ However, it is still too early to evaluate the actual mortality rate of the disease, considering the rapid spread of COVID-19. Old age, ischaemic 
heart disease, hypertension, diabetes mellitus, chronic lung disease, cancer and patients receiving immunosuppressive medicines are the major risk factors for poor outcomes. ${ }^{59}$

\section{BCG Vaccine and Its Impact on Viral Infections}

BCG as a live attenuated vaccine against TB was developed from a virulent strain of Mycobacterium bovis (M. bovis) at the Institut Pasteur in Paris. In the 1950s, clinical trials on BCG vaccine were initiated in both UK and USA, and accordingly, the use of BCG vaccine was recommended by the UK, but in USA, it was restricted only to high-risk populations. Since then, most countries have followed BCG vaccination policies. The distribution of BCG vaccine to many laboratories worldwide and the repeated subculture in the different countries resulted in the emergence of phenotypically different vaccine strains. ${ }^{69}$ Continuing studies are trying to determine the effect of the genomic diversity amongst BCG vaccine strains.

There is an available database for policies and practices of BCG worldwide, the BCG World Atlas. ${ }^{70}$ BCG vaccine was never used in the national vaccination program of Italy. Spain, Germany and the UK stopped systematic BCG vaccination in 1981, 1998 and 2005, respectively. ${ }^{71}$ Currently, countries that have mandatory BCG policies include Argentina, Brazil, Bulgaria, Chile, China, Egypt, Estonia, Iran, Ireland, Japan, Mexico, Poland, Singapore, South Africa, Taiwan, Thailand and Turkey. ${ }^{70,71}$ For information about the current and past BCG vaccination policies and practices for more than 180 countries, the BCG World Atlas and interactive map are used. ${ }^{70} \mathrm{BCG}$ is given to newborns with high protective effect against tuberculous meningitis and miliary $\mathrm{TB}$, but this effect is significantly lower against pulmonary TB. In the case of adults, BCG vaccination does not fully protect against pulmonary $\mathrm{TB}$, which could explain why $\mathrm{TB}$ is one of the leading causes of death worldwide.

Interestingly, BCG also reduces infant mortality, which could be attributed to the non-specific cross-defence against other, unrelated pathogens. ${ }^{72}$ BCG vaccine shows a lower risk of developing respiratory tract infections such as influenza A virus, RSV and HSV2. ${ }^{36-41}$ Additionally, with BCG vaccination, West African studies have shown significant decreases in malaria mortality, sepsis, respiratory infections, and leprosy. Overall, decreased infant mortality due to BCG vaccination has been observed in many countries. ${ }^{73}$ Furthermore, BCG could be used in treatment of other diseases such as bladder cancer, warts, leishmaniasis, candidiasis and asthma. ${ }^{74}$ Table 1 highlights the non-specific effects of BCG vaccine on different viral infections. Moreover, BCG vaccine helps in the production of other vaccines against pathogenic bacteria and viruses. This is due to its safety for a long time in vaccinated neonates, children and adults and because BCG antigens can act as adjuvants, inducing innate and adaptive immune responses. ${ }^{73} \mathrm{In}$ humans, limited clinical evidence suggests that BCG vaccination may have non-targeted protective effects against viral infections. Many studies have been performed to explain the mechanisms behind these non-targeted protective effects of BCG. ${ }^{37,75,76}$

\section{Immune Response to BCG Vaccine}

Generally, vaccines work by activation of the adaptive immune response and formation of immunological memory of antigen-specific $\mathrm{T}$ and $\mathrm{B}$ cells to target the pathogens. ${ }^{95}$ Following BCG vaccination, the bacilli are recognized and identified at the inoculation site by neutrophils, macrophages, and dendritic cells (DCs) to start the immune response (Figure 1), where pathogen-associated molecular patterns (PAMPs) expressed by mycobacteria (such as peptidoglycan, arabinogalactan, and mycolic acids) interact with pattern recognition receptors (PRRs) expressed on innate immune cells, stimulating the macrophage, maturation of DCs and pro-inflammatory cytokines release. ${ }^{96-99}$

PRRs, which are involved in BCG recognition and internalization, include toll-like receptors (TLRs), nucleotide oligomerization domain (NOD)-like receptors, complement receptors (CR3 and CR4), CD14 receptors, and C-type lectins such as dendritic cell-specific intercellular adhesion molecule grabbing nonintegrin (DC-SIGN) ${ }^{96,99}$ Maturation and migration of DCs to the nearest secondary lymphoid tissues or spleen are associated with increased expression of costimulating molecules (CD40, CD80, CD83 and CD86). ${ }^{100}$ Antigen (Ag) 85, which found in BCG cell wall and M. tuberculosis, triggers production of tumor necrosis factoralpha (TNF- $\alpha$ ), interleukin 1-beta (IL-1 $\beta$ ) and IL-6, resulting in a pro-inflammatory state to activate immune cells. ${ }^{101}$

The adaptive immune response develops when antigenpresenting cells (DCs, macrophages, and B cells) present antigenic peptides on MHC and primary T cells in lymph nodes. ${ }^{102}$ In lymph nodes, BCG infected DCs release IL-6, IL-12 and TNF- $\alpha$ as well as triggering activation of $\mathrm{CD}^{+}$ and $\mathrm{CD}^{+} \mathrm{T}$ cells with high production of IFN- $\gamma .{ }^{103} \mathrm{Ten}$ weeks after vaccination, in the blood mycobacteria-specific $\mathrm{CD}^{+} \mathrm{T}$ cells proliferate and release IFN- $\gamma$ and express 
Table I Overview of the Non-Specific BCG Vaccine Effects Described for Different Viral Infections (Adapted from Moorlag et al. ${ }^{77}$ )

\begin{tabular}{|c|c|c|c|c|}
\hline & Virus & Study Type & Effect of BCG & Ref. \\
\hline \multirow{6}{*}{$\begin{array}{l}\text { Human } \\
\text { Studies }\end{array}$} & Yellow fever vaccine & RCT & Reduced yellow fever vaccine titres correlating with IL-Ib production & [78] \\
\hline & \multirow[t]{2}{*}{$\mathrm{HPV}$} & RCT & \multirow[t]{2}{*}{ Improved clearance of viral warts } & \multirow[t]{2}{*}{ [79-8I] } \\
\hline & & Case series & & \\
\hline & RSV & $\begin{array}{l}\text { Case control } \\
\text { study }\end{array}$ & $\begin{array}{l}\text { Non-significant association of fewer RSV infections in Guinea-Bissau in } \\
\text { young children (girls) }\end{array}$ & {$[41]$} \\
\hline & Influenza A (HINI) & $\mathrm{RCT}$ & Enhanced antibody production & {$[82]$} \\
\hline & HSV & Case series & Reduced episodes of clinical HSV infection & {$[83,84]$} \\
\hline \multirow{13}{*}{$\begin{array}{l}\text { Animal } \\
\text { Studies }\end{array}$} & HSV I & CD-I mice & Enhanced survival & {$[85]$} \\
\hline & \multirow[t]{2}{*}{ HSV 2} & - & Enhanced survival and protection from infection & {$[37]$} \\
\hline & & CD-I mice & & {$[85]$} \\
\hline & \multirow[t]{3}{*}{ Influenza A } & - & Reduced viral titres of against influenza $A$ virus & [76] \\
\hline & & C57BI/6 mice & Reduced inflammation & {$[86]$} \\
\hline & & CD-I mice & Enhanced survival & {$[85]$} \\
\hline & Influenza A (H7N9) & $\mathrm{BALB} / \mathrm{c}$ mice & No increased protection & {$[87]$} \\
\hline & Hepatitis B & C57BI/6 mice & Enhanced antibody production & [88] \\
\hline & Japanese encephalitis & BALB/c mice & Delayed occurrence of clinical symptoms and increased survival & [89] \\
\hline & $\begin{array}{l}\text { Encephalomyocarditis } \\
\text { virus }\end{array}$ & $\begin{array}{l}\text { C57B } 1 / 10 \\
\text { mice }\end{array}$ & Enhanced resistance (induced by non-viable $M$. tuberculosis) & {$[90,91]$} \\
\hline & Ectromelia virus & DDN mice & Enhanced survival and increased IFN-g production & {$[92,93]$} \\
\hline & \multirow[t]{2}{*}{ Vaccinia } & $\mathrm{BALB} / \mathrm{c}$ mice & Protection from infection (induced by MDP) & {$[75]$} \\
\hline & & C57BI/6 mice & Protection from infection and increased IFN-g production & [94] \\
\hline
\end{tabular}

Abbreviations: RCT, Randomized control trial; HPV, Human papillomavirus; RSV, Respiratory syncytial virus; HSV, Herpes simplex virus; CD-I mice, Outbred mice, generally used for genetics, toxicology, pharmacology, and ageing research; C57BL/6 mice, common inbred strains of laboratory mice; BALB/c mice, an albino, laboratorybred strain of house mouse; C57BL/10 mice, superficially identical to C57BL/6 mice in appearance and behaviour and widely used in inflammation and immunology research; DDN mice, inbred albino mice with distinctive characteristics of the central nervous system; IFN-g, Interferon gamma; MDP, Muramyldipeptide.

granzymes. $^{104}$ Additionally, IFN- $\gamma$, TNF- $\alpha$, and IL-2 are released by activated TH1 CD4 ${ }^{+}$T cells. ${ }^{105}$ Moreover, BCGinfected neutrophils team up with DCs (BCG-infected), stimulating the responses of antigen-specific T cells. ${ }^{106}$ The released IFN- $\gamma$ activates B cells and leads to generation of memory and plasma cells, releasing antigen-specific antibodies, which are able to opsonize BCG and M. tuberculosis, inhibiting intracellular bacterial growth. ${ }^{107}$

\section{BCG Vaccine Reprogrammes Innate Immunity (Trained Immunity)}

As a consequence of BCG vaccination, an increased nonspecific response to unrelated pathogens is mediated through induction of innate immune cells including monocytes/macrophages and $\mathrm{NK}$ cells and independent of $\mathrm{T}$ and $\mathrm{B}$ cell responses (trained immunity) (Figure 2). Trained immunity following BCG vaccination is associated with elevated production of pro-inflammatory cytokines (e.g. TNF- $\alpha$, IL-1 $\beta$ and IL-6), achieving significant protection against different viral infections. ${ }^{108,109}$

One of the molecular mechanisms behind trained immunity is the epigenetic reprogramming of monocytes through histone modifications (methylation and acetylation of histone) in regulatory elements of specific genes (such as TNF$\alpha$, IL-6, and IL-1 $\beta$ ). ${ }^{43,109,110}$ This histone modification results in enhanced chromatin accessibility and easier transcription of genes, which are related to increased antimicrobial responses and enhanced cell function. ${ }^{110}$ Accordingly, 


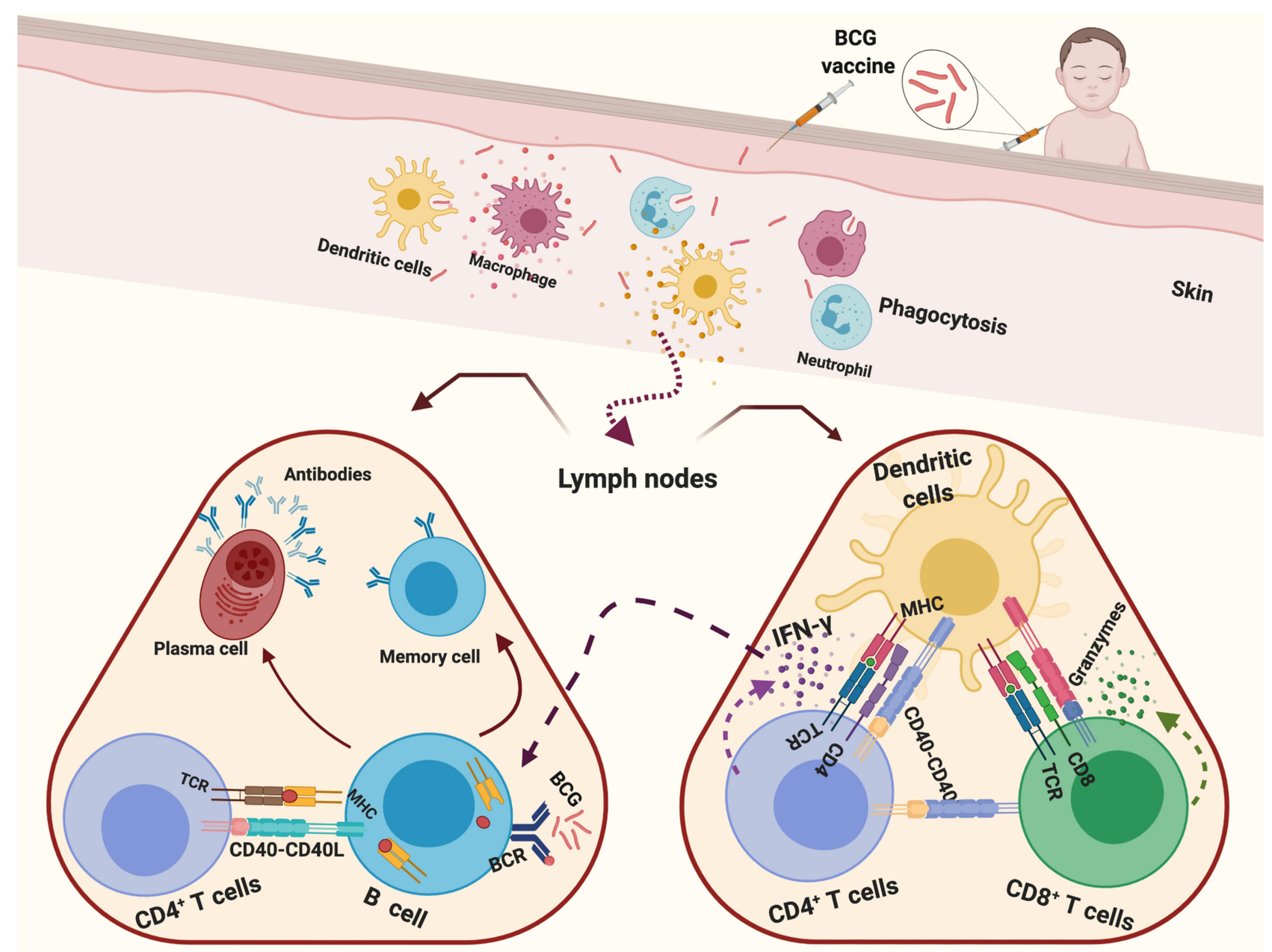

Figure I Schematic representation of the immune response elicited by BCG vaccination.

Notes: First, neutrophils, macrophages and dendritic cells recognize BCG at the inoculation site. Then the activated dendritic cells migrate to lymph nodes, activating the adaptive immune cells. $\mathrm{CD}^{+}$and $\mathrm{CD}^{+} \mathrm{T}$ cells are activated, releasing IFN- $\gamma$ and granzymes. Activation of $\mathrm{B}$ cells results in production of memory and plasma cells with the release of antigen-specific antibodies.

when BCG-epigenetically trained monocytes are exposed to another pathogen (viruses and bacteria as pathogenassociated molecular patterns), PPRs easily and rapidly recognize it, leading to increased cytokine production (e.g. TNF- $\alpha$, IL-1 $\beta$ and IL-6). ${ }^{95}$ Additionally, metabolic reprogramming results in selective accumulation or depletion of some metabolites, which regulate epigenetic changes.

\section{BCG Vaccine as a Tool Against COVID-I 9}

SARS-CoV-2 is a single-stranded RNA virus. A vital encoded structural protein within its RNA chain is Spike glycoprotein (S), which consists of three heterodimers of S1-S2 that bind to the angiotensin-converting enzyme 2 (ACE2) type II pneumocyte receptor. SARSCoV-2 enters host cells by endocytosis and then multiplies in the cytoplasm, leading to cell apoptosis due to high protein manufacturing stress. Coronaviral RNA itself works as a PAMP and it is recognized by a PRR or TLR, resulting in a chemokinetic surge that causes migration and activation of neutrophils, leading to destruction of the alveolar-capillary walls. At the microscopic level, this results in a loss of the interface between intra-alveolar space and the surrounding stroma and subsequently, the fluids leak and fill the alveolar sacs. ${ }^{111}$ Trained immunity could have a potential protective effect against COVID-19.

The association of some vaccines (such as BCG, adult pneumococcal and adult seasonal influenza) with COVID19 mortality has been studied, suggesting that BCGvaccinated individuals have reduced mortality rates. ${ }^{43,112}$ $\mathrm{BCG}$, as the most prominent example for induction of 


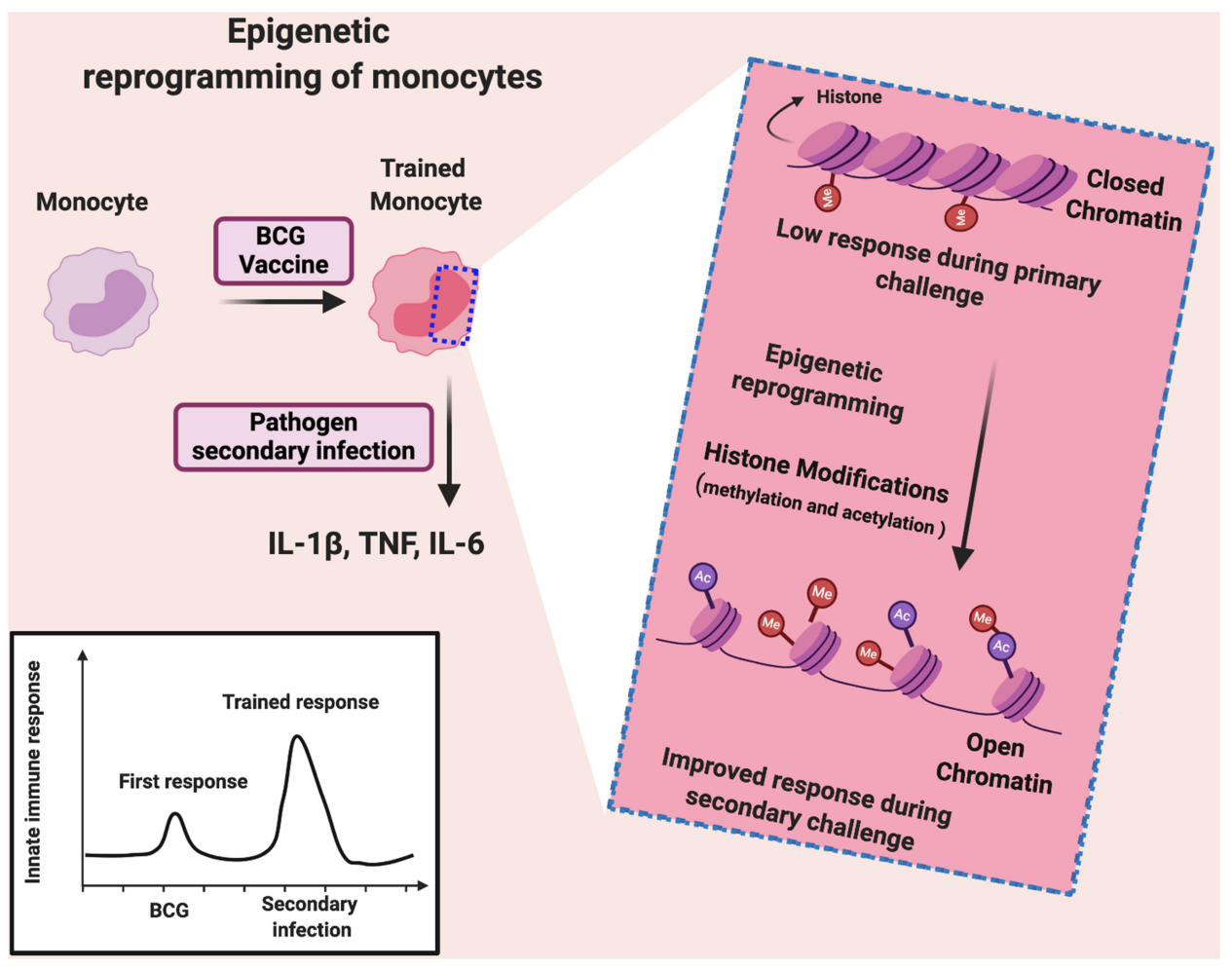

Figure 2 Trained immunity mediated by epigenetic reprogramming of monocytes.

trained immunity, shows a broad-spectrum protection, which is not only against $\mathrm{TB}$, but also against unrelated infections, especially respiratory tract infections. ${ }^{36-41,72}$ Interestingly, several ecological studies observed that there is an inverse correlation between BCG vaccination and COVID-19 prevalence and mortality, suggesting a potential protective effect of BCG against COVID$19 .^{42-46,113-116}$

The cooperation between the innate and adaptive immune system plays a crucial role to defend against viral infections. Although the current review focuses on BCG vaccine-related trained immunity in terms of COVID-19, another mechanism of cross-protection was recently reported as BCG vaccine may generate crossreactive $\mathrm{T}$ cells against SARS-CoV-2 because BCG has been shown to contain similar 9-amino acid sequences with SARS-CoV-2, and those closely related peptides have moderate to high binding affinity to common HLA class I molecules. ${ }^{117}$

Moreover, BCG vaccination can modulate antiinflammatory cytokine and chemokine responses, preventing hospitalization and resulting in less severe cases of COVID-19. ${ }^{118,119}$ This could be attributed to the suggestion that $\mathrm{BCG}$ vaccine modulates the innate immune system.
Based on these studies, countries with BCG in their national vaccination programmes (BCG countries) show lower numbers of confirmed COVID-19 cases/million inhabitants than countries with no BCG vaccination policy (nonBCG countries) (Figure 3). ${ }^{43,116,120}$ Further, amount of deaths/million inhabitants in BCG countries is lower than in non-BCG countries (Figure 3C and D). ${ }^{43,116,120}$ Escobar et al. ${ }^{8}$ showed that each $10 \%$ increase in $\mathrm{BCG}$ index was associated with a decrease in COVID-19 mortality by $10.4 \%$. Also, Gallagher et al. ${ }^{112}$ found that $64 \%$ reduction in $\log (10)$ mortality/10 million population is associated with BCG vaccination. Moreover, a negative correlation was observed between cases and deaths of COVID-19 and the years following BCG administration. ${ }^{121}$ A research study (published in October 2020) also revealed fewer COVID-19 cases in BCG countries including Afghanistan, India, Bangladesh, Nepal and Japan compared with non-BCG countries including the USA, UK, Canada, Italy and Spain. ${ }^{122}$

The negative correlation between routine infant BCG vaccination and COVID-19 spread in young people was recorded across different countries in several studies. ${ }^{123-125}$ BCG vaccination under 25 years of age showed a protective effect against COVID-19. ${ }^{121,123,125}$ Twenty-seven BCG countries (either at birth or during 
A
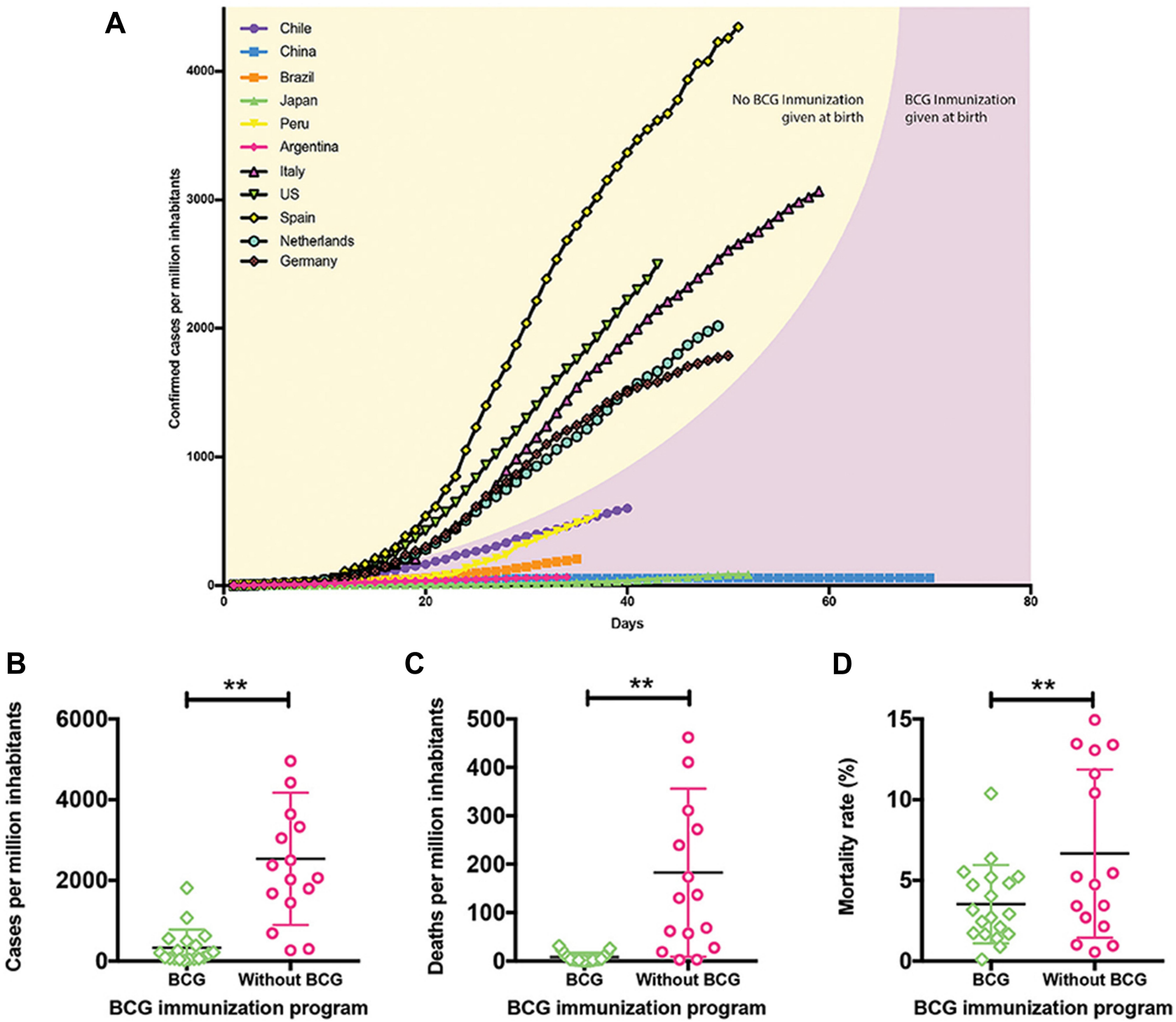

Figure 3 Protective effect of BCG vaccine against COVID-19.

Notes: (A) COVID-19 cases in different countries starting from the day at which the cases exceeded 2 cases/million till few months of the pandemic (April 2020). Curves of countries without BCG vaccination program are in the yellow background and curves of countries with BCG vaccination program at birth are in the pink background, (B) Confirmed cases/per million inhabitants in BCG- and non-BCG countries, (C) deaths/million inhabitants, and (D) mortality rates in BCG- and non-BCG countries. This figure is based on collected data till April 2020. ** Statistically significant differences between the groups. Reproduced from Covián C, Retamal-Díaz A, Bueno SM, Kalergis AM. Could BCG vaccination induce protective trained immunity for SARS-CoV-2? Frontiers in Immunology. 2020; I I:970. Copyright (C 2020 Covián, Retamal-Díaz, Bueno and Kalergis. Creative Commons Attribution License (CC BY). ${ }^{43}$

childhood) showed lower mortality than that for 23 nonBCG countries $(\mathrm{P}<0.001){ }^{123}$

Most of these correlational ecological studies were carried out during the first few months of the COVID-19 pandemic. $^{42-46,126}$ As with any observational epidemiological study, the collected data (such as data in Figure 3) are interpreted as a hypothesis only, which further needs detailed studies to confirm. Thus, further investigations considering the differences between countries including demographics, socioeconomic status, climate, testing rate, pandemic stage and infection prevention protocols are required.

Importantly, clinical studies are also essential to draw a conclusion regarding the role of $\mathrm{BCG}$ vaccine against COVID-19. ${ }^{49}$ Accordingly, some countries have started clinical studies to confirm whether BCG vaccine is able to protect healthcare workers against SARS-CoV-2 infection and the recruitment in these clinical trials has started (Table 2). ${ }^{127,128}$ Table 2 shows different clinical trials around the world, which are planned to randomize 


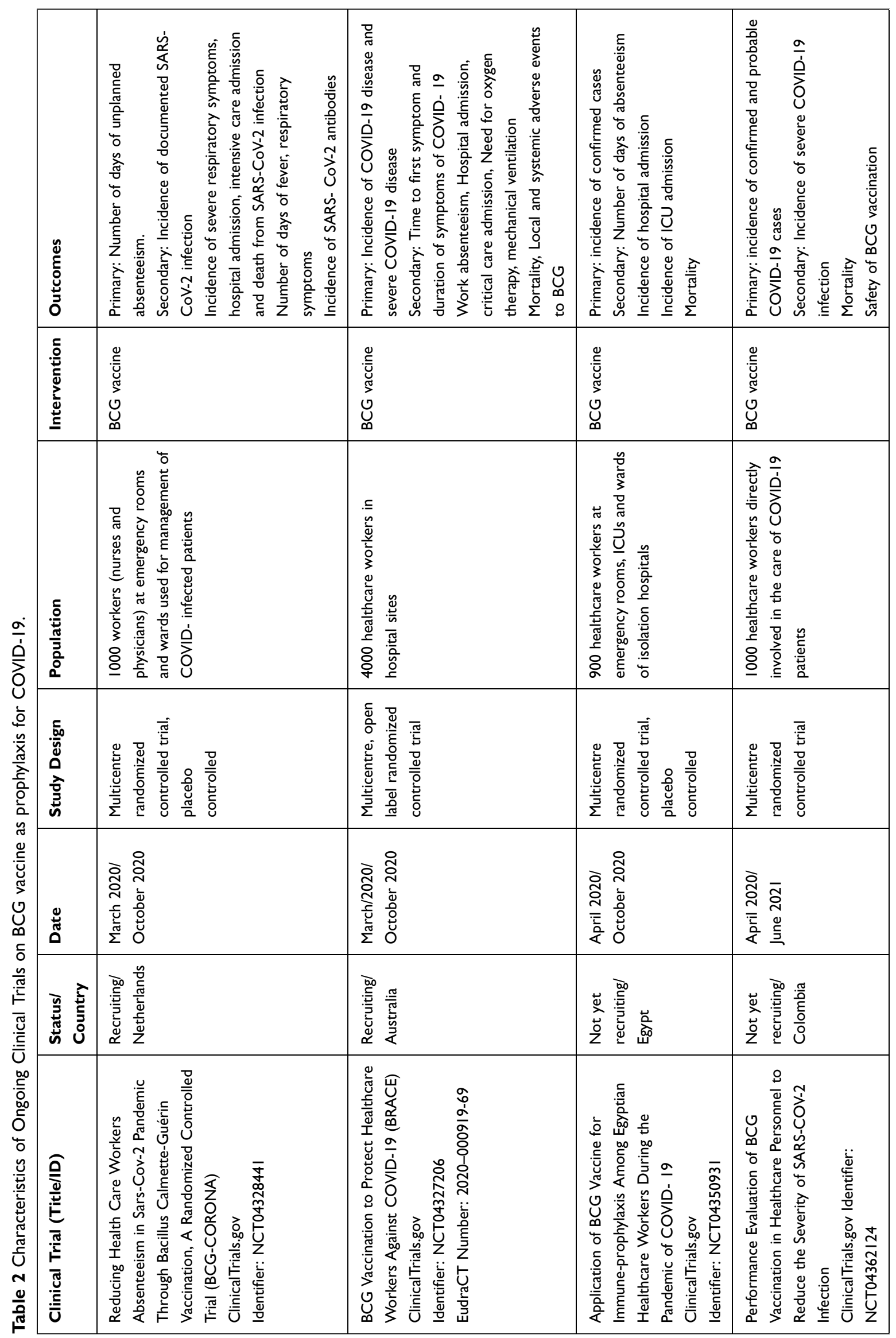




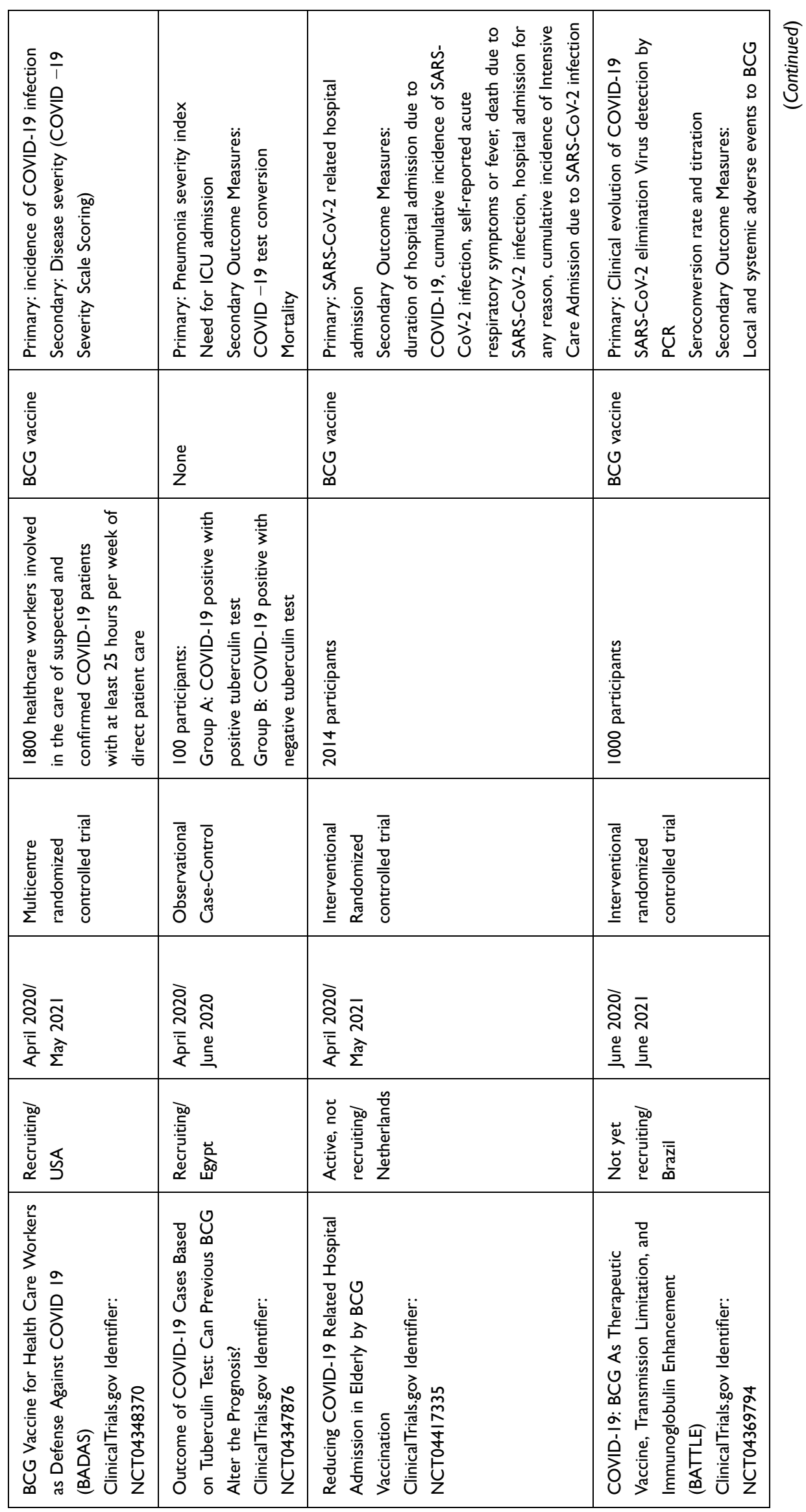




\begin{tabular}{|c|c|c|c|}
\hline 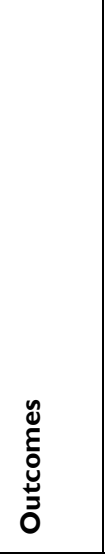 & 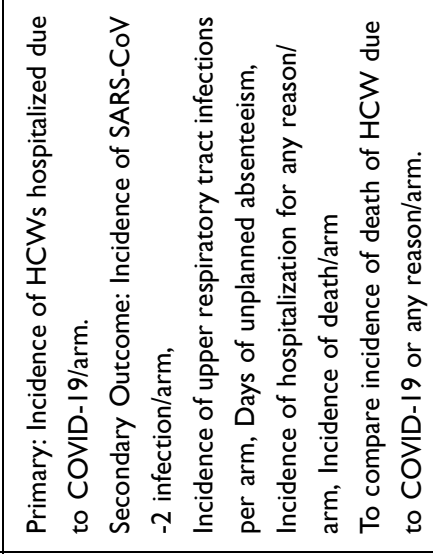 & 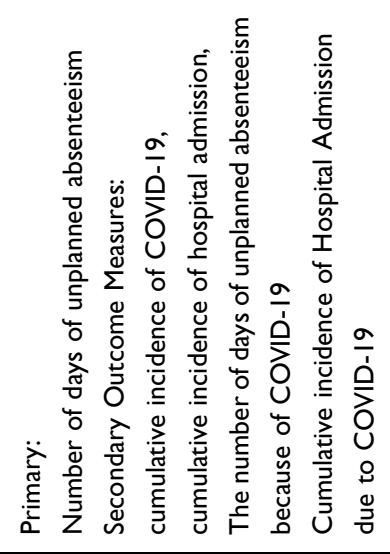 & 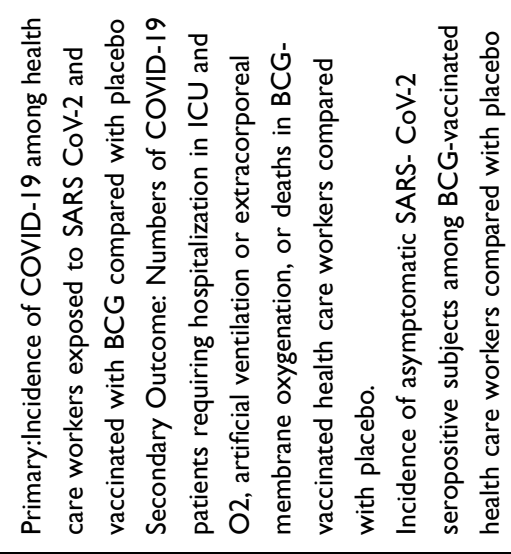 \\
\hline 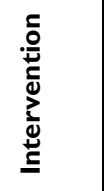 & 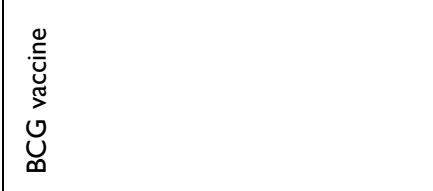 & 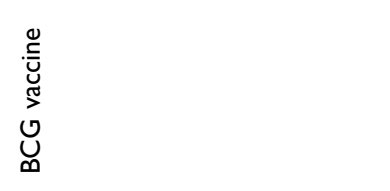 & 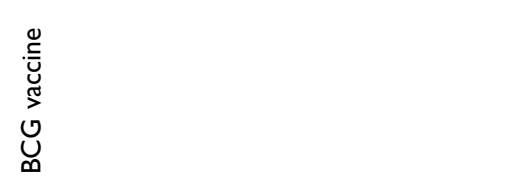 \\
\hline & 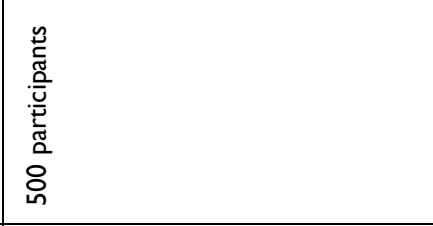 & 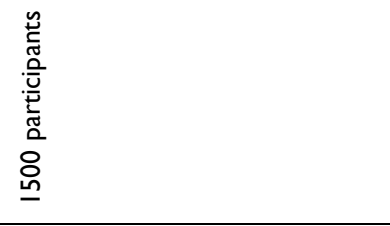 & 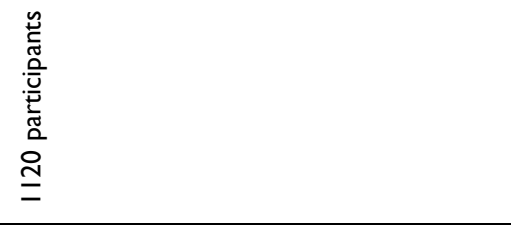 \\
\hline 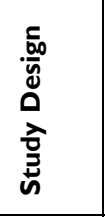 & 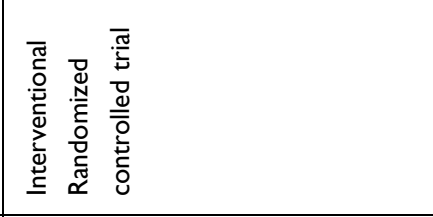 & 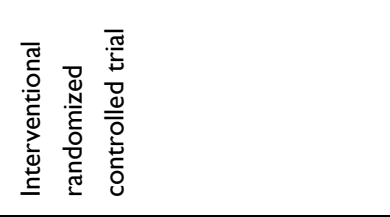 & 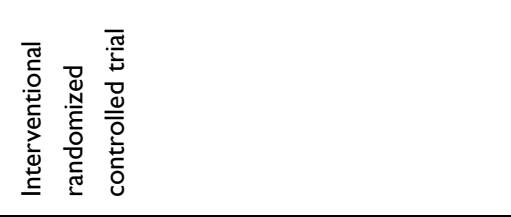 \\
\hline ט̆ & 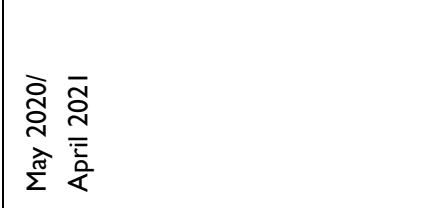 & 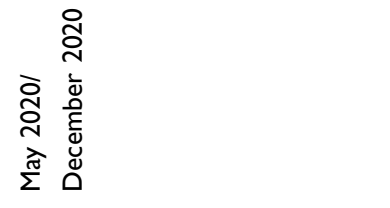 & 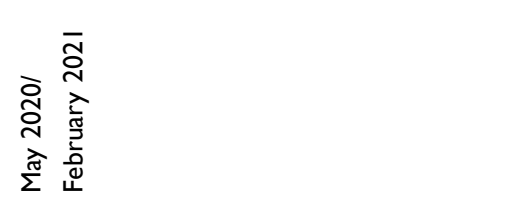 \\
\hline 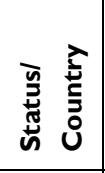 & 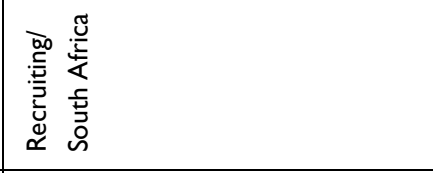 & 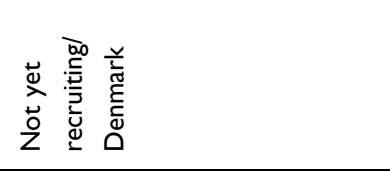 & 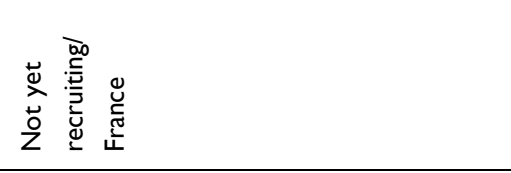 \\
\hline 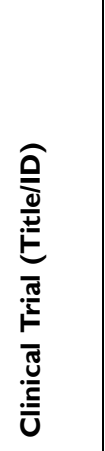 & 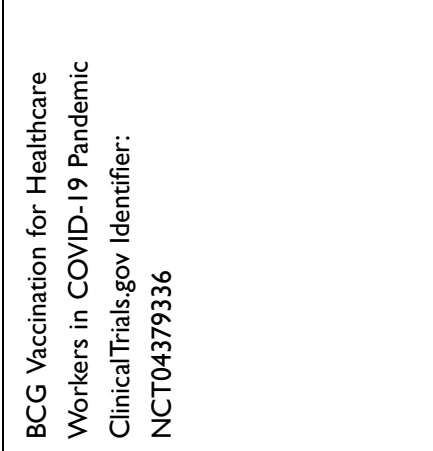 & 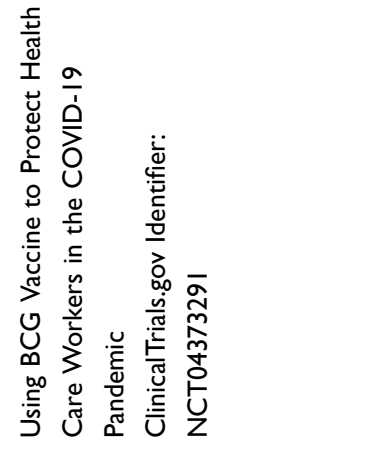 & 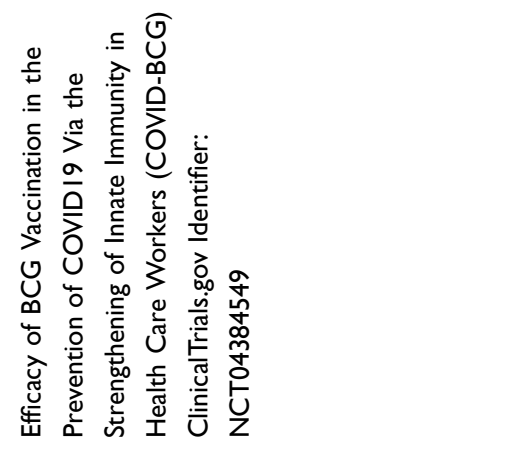 \\
\hline
\end{tabular}




\begin{tabular}{|c|c|c|c|}
\hline 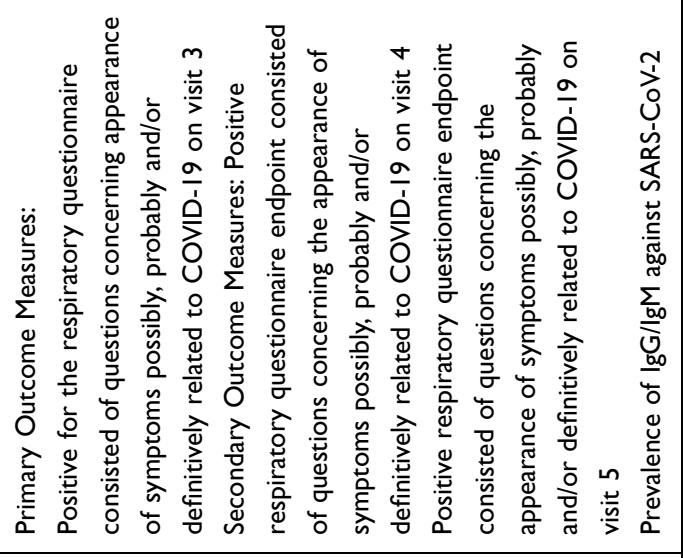 & 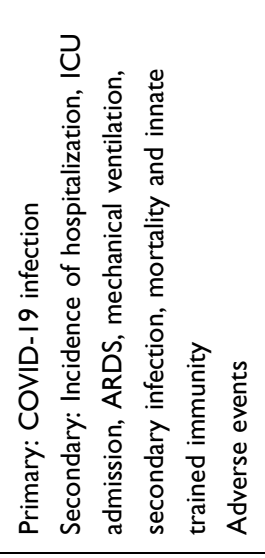 & 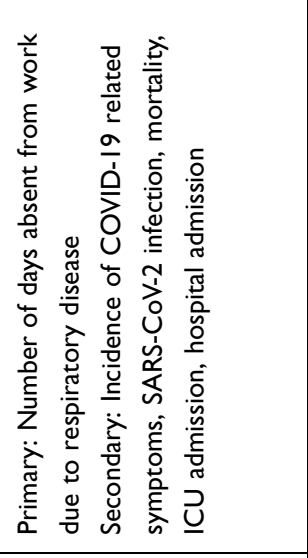 & 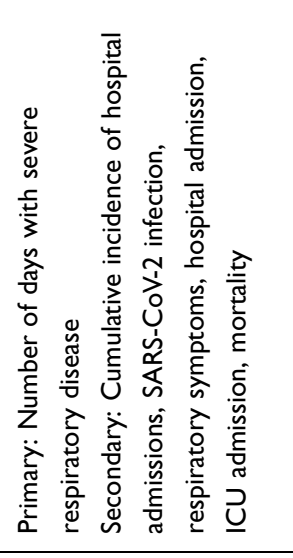 \\
\hline 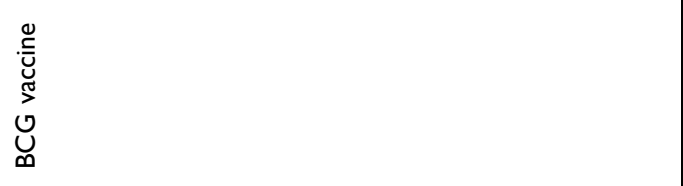 & 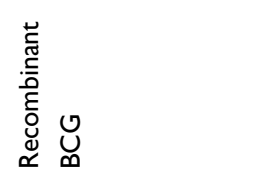 & 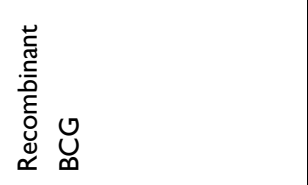 & 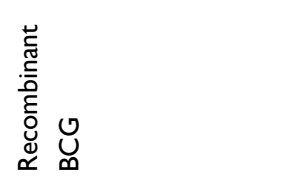 \\
\hline 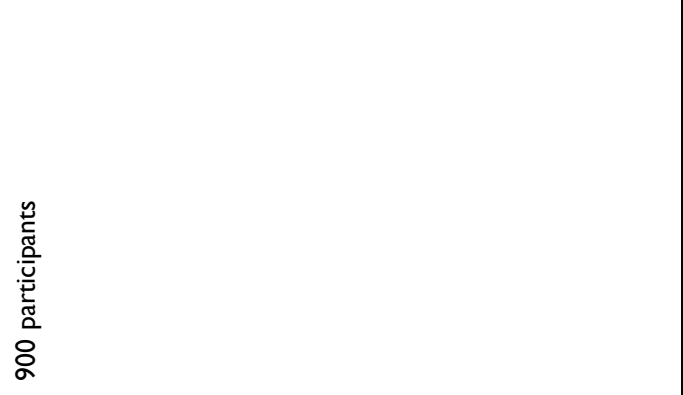 & 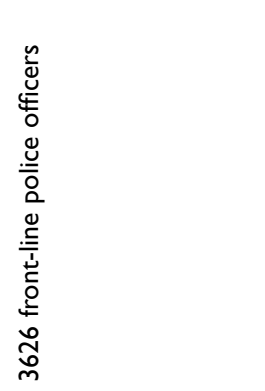 & 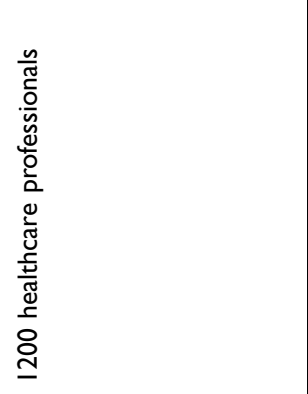 & 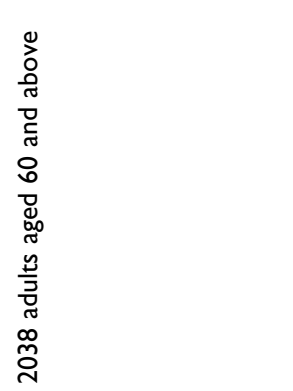 \\
\hline 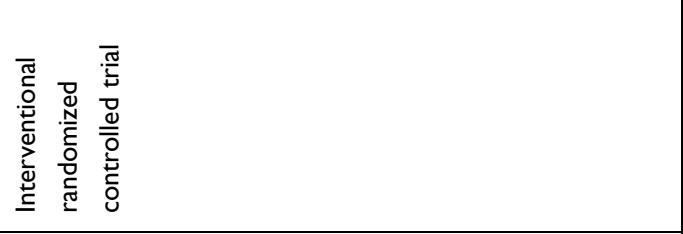 & 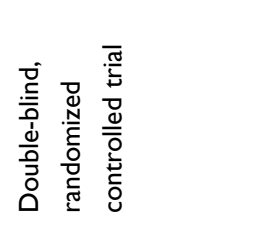 & 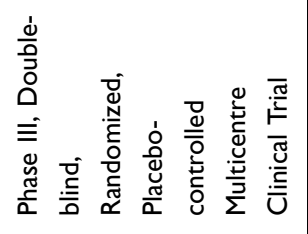 & 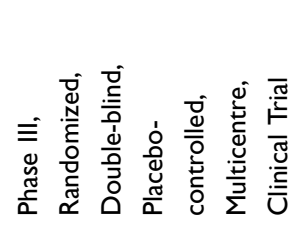 \\
\hline 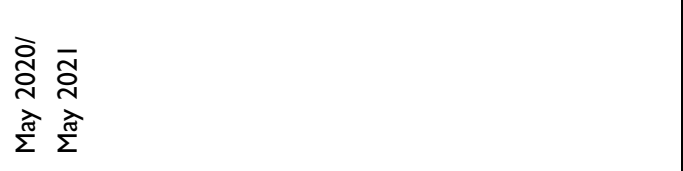 & 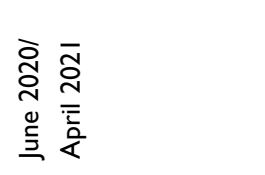 & 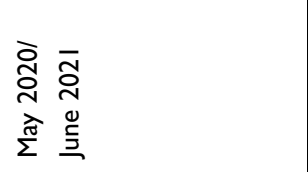 & 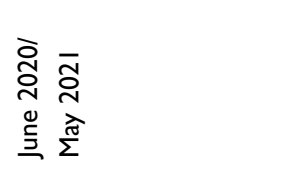 \\
\hline 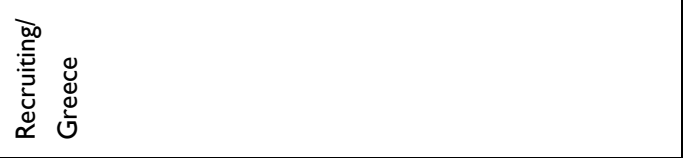 & 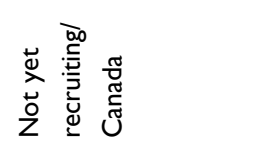 & 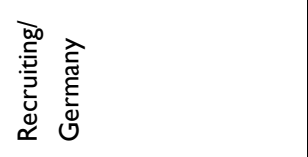 & 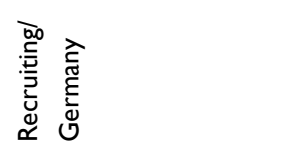 \\
\hline 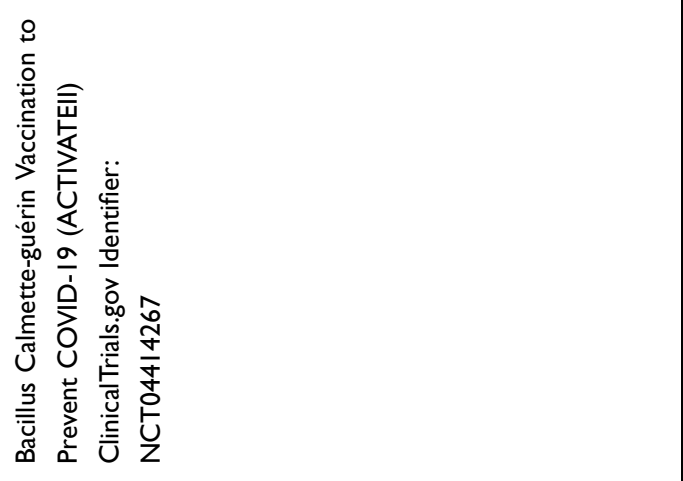 & 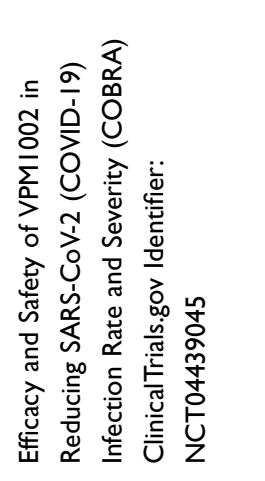 & 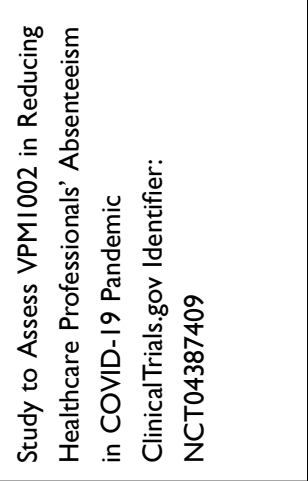 & 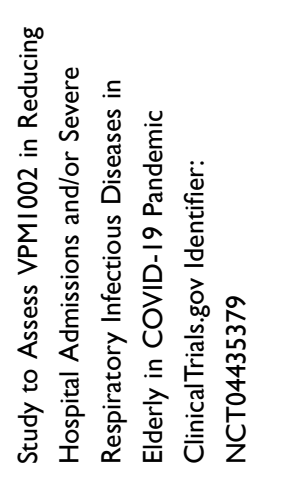 \\
\hline
\end{tabular}


cumulatively more than 10,000 BCG-immunization healthcare workers. Different primary outcomes are measured in each study. In the case of the Australian and American designs, they assess incidence of COVID-19 and disease symptoms; however, the Dutch group is looking primarily at absenteeism of the healthcare workers. The fourth observational case-control study in Egypt, started recruitment of positive COVID-19 cases and compares the disease severity in thoracic patients. ${ }^{129}$ Another study in Germany is done to test whether VPM1002 (a recombinant vaccine strain derived from BCG), can protect either healthcare workers or older patients from COVID-19. ${ }^{130}$

Based on the results of these clinical studies, we can confirm if there is a protective effect of BCG vaccination against COVID-19. However, further studies will be required to answer many questions about this protection. First, for how long does this BCG-engendered heterologous immunity last after BCG vaccination? And if this trained immunity will last for a few months after vaccination and then gradually decrease. Second, what is the best timing for BCG vaccination? And if the early life BCG vaccination (before age of nine months) results in better effects on respiratory infections and COVID-19 than later vaccinations $?^{43,131}$ Importantly, these questions should be carefully studied to answer all the raised concerns regarding insufficient evidence between BCG vaccination and COVID-19 protection. ${ }^{132}$ Additionally, mechanistic studies are still required to decipher the mechanisms behind the correlation between BCG-induced trained immunity and COVID-19.

Until now, the WHO still recommends that BCG vaccine should be used against COVID-19 only in randomized controlled trials for a number of reasons, a) uncertain ability of BCG to protect against COVID-19, b) shortage of BCG vaccine, c) false sense of safety, d) BCG vaccine may be affected by subsequent administration of another vaccine and e) up-regulation of immunity by BCG could worsen COVID-19 in some critically ill patients. ${ }^{133,134}$ Another important aspect relates to boosting BCG's innate immune response and complications in COVID-19 patients due to an exaggerated cytokine response. This hypothesis requires further clarification because it was noticed that BCG-vaccinated healthy individuals had induced trained immunity, which enhanced the antimicrobial properties, and reduced viral loads, resulting in less inflammation and symptoms. ${ }^{44,135}$ On the contrary, older people as a high-risk group have defective antiviral response, resulting in high viral loads and systemic inflammation. The suggestion that BCG's induction of trained immunity may provide a defence against COVID-19 must be evaluated in randomized clinical trials.

Interestingly, inductions of qualified immunity against COVID-19 may not be restricted to BCG because oral polio vaccines are suspected to protect against unrelated viral infections, and the recombinant BCG-based vaccine (VPM1002) may also be considered for clinical trials. ${ }^{136}$ Therefore, BCG vaccine or other trained immunity inducers, which provide non-specific protection, would be an important tool in responding to COVID-19 and future pandemics.

\section{Conclusion}

Currently, the COVID-19 pandemic has put the entire globe in an unprecedented crisis, which requires rapid development of effective vaccine or treatment. BCG, as a live attenuated vaccine, reduces infant mortality due to the non-specific cross-defence against other unrelated pathogens including respiratory tract infections. During the first months of the pandemic, several epidemiological studies revealed an inverse correlation between BCG vaccination and COVID-19 incidence and mortality. Because there is a debate around the non-specific protection of BCG, results from several ongoing clinical trials in different countries are awaited to confirm the correlation between BCG vaccination and COVID-19 and caution should be considered in the interpretation of the related results. Strong evidence about any protective role of BCG vaccination should be concluded before reflecting on practice and vaccination policies.

\section{Acknowledgments}

All the figures were created with BioRender.com. KM's work is supported by UAE University-start up Grant \# G3347 and UAEU-UPAR-Grant\#G3458.

\section{Author Contributions}

All authors made substantial contributions to conception and design, acquisition of data, analysis and interpretation of data; took part in drafting the article or revising it critically for important intellectual content; agreed to submit to the current journal; gave final approval of the version to be published; and agree to be accountable for all aspects of the work.

\section{Disclosure}

The authors declare no conflicts of interest for this work. 


\section{References}

1. Coleman CM, Frieman MB. Coronaviruses: important emerging human pathogens. J Virol. 2014;88(10):5209-5212. doi:10.1128/ JVI.03488-13

2. Lau SKP, Woo PCY, Li KSM, et al. Severe acute respiratory syndrome coronavirus-like virus in Chinese horseshoe bats. Proc Natl Acad Sci U S A. 2005;102(39):14040-14045. doi:10.1073/pnas.0506735102

3. Dar HA, Waheed Y, Najmi MH, et al. Multiepitope Subunit Vaccine Design against COVID-19 Based on the Spike Protein of SARS-CoV-2: an In Silico Analysis. $J$ Immunol Res. 2020;2020:1-15. doi:10.1155/2020/8893483

4. Abid SA, Suhail A, Al-Kadmy IM, et al. Biosensors as a future diagnostic approach for COVID-19. Life Sci. 2021;273:119117. doi:10.1016/j.1fs.2021.119117

5. Corman VM, Ithete NL, Richards LR, et al. Rooting the phylogenetic tree of middle East respiratory syndrome coronavirus by characterization of a conspecific virus from an African bat. J Virol. 2014;88(19):11297-11303. doi:10.1128/JVI.01498-14

6. van Boheemen S, de Graaf M, Lauber C, et al. Genomic characterization of a newly discovered coronavirus associated with acute respiratory distress syndrome in humans. mBio. 2012;3(6): e00473. doi:10.1128/mBio.00473-12

7. Zaki AM, van Boheemen S, Bestebroer TM, Osterhaus ADME, Fouchier RAM. Isolation of a Novel Coronavirus from a Man with Pneumonia in Saudi Arabia. $N$ Eng J Med. 2012;367 (19):1814-1820. doi:10.1056/NEJMoa1211721

8. Escobar LE, Molina-Cruz A, Barillas-Mury C, Vaccine BCG. Protection from Severe Coronavirus Disease 2019 (COVID19). medRxiv. 2020. doi:10.1101/2020.05.05.20091975

9. WHO. WHO announces COVID-19 outbreak a pandemic; 2020. Available from: http://www.euro.who.int/en/health-topics/healthemergencies/coronavirus-covid-19/news/news/2020/3/whoannounces-covid-19-outbreak-a-pandemic. Accessed March 3, 2021.

10. WHO. Coronavirus disease, Weekly epidemiological update February 2021; 2021. Available from: https://www.who.int/publi cations/m/item/weekly-epidemiological-update-16-february -2021. Accessed March 3, 2021.

11. Wang M, Cao R, Zhang L, et al. Remdesivir and chloroquine effectively inhibit the recently emerged novel coronavirus (2019-nCoV) in vitro. Cell Res. 2020;30(3):269-271. doi:10.1038/s41422-020-0282-0

12. Holshue ML, DeBolt C, Lindquist S, et al. First Case of 2019 Novel Coronavirus in the United States. $N$ Eng J Med. 2020;382 (10):929-936. doi:10.1056/NEJMoa2001191

13. Reina J. Remdesivir, the antiviral hope against SARS-CoV-2. Rev Espanola de Quimioterapia. 2020;33(3):176-179. doi:10.37201/ req $/ 028.2020$

14. Sheahan TP, Sims AC, Leist SR, et al. Comparative therapeutic efficacy of remdesivir and combination lopinavir, ritonavir, and interferon beta against MERS-CoV. Nat Commun. 2020;11 (1):222. doi:10.1038/s41467-019-13940-6

15. Kruse RL. Therapeutic strategies in an outbreak scenario to treat the novel coronavirus originating in Wuhan, China. F1000Res. 2020;9:72. doi:10.12688/f1000research.22211.2

16. Cascella M, Rajnik M, Cuomo A, Dulebohn SC, Di Napoli R. Features, Evaluation and Treatment Coronavirus (COVID-19). StatPearls [Internet]: StatPearls Publishing; 2020.

17. Zumla A, Chan JFW, Azhar EI, Hui DSC, Yuen K-Y Coronaviruses - drug discovery and therapeutic options. Nat Rev Drug Discov. 2016;15(5):327-347.
18. Al-Tawfiq JA, Momattin H, Dib J, Memish ZA. Ribavirin and interferon therapy in patients infected with the Middle East respiratory syndrome coronavirus: an observational study. Int J Infect Dis. 2014;20:42-46. doi:10.1016/j.ijid.2013.12.003

19. Wu C-Y, Jan J-T, Ma S-H, et al. Small molecules targeting severe acute respiratory syndrome human coronavirus. Proc Natl Acad Sci U S A. 2004;101(27):10012. doi:10.1073/pnas.0403596101

20. Chu CM, Cheng VCC, Hung IFN, et al. Role of lopinavir/ritonavir in the treatment of SARS: initial virological and clinical findings. Thorax. 2004;59(3):252-256. doi:10.1136/thorax.2003.012658

21. Cao B, Wang Y, Wen D, et al. A Trial of Lopinavir-Ritonavir in Adults Hospitalized with Severe Covid-19. $N$ Eng J Med. 2020;382(19):1787-1799. doi:10.1056/NEJMoa2001282

22. Savarino A, Di Trani L, Donatelli I, Cauda R, Cassone A. New insights into the antiviral effects of chloroquine. Lancet Infect Dis. 2006;6(2):67-69. doi:10.1016/S1473-3099(06)70361-9

23. Yan Y, Zou Z, Sun Y, et al. Anti-malaria drug chloroquine is highly effective in treating avian influenza A H5N1 virus infection in an animal model. Cell Res. 2013;23(2):300-302. doi:10.1038/cr.2012.165

24. Vincent MJ, Bergeron E, Benjannet S, et al. Chloroquine is a potent inhibitor of SARS coronavirus infection and spread. Virol J. 2005;2(1):69. doi:10.1186/1743-422X-2-69

25. Rolain J-M, Colson P, Raoult D. Recycling of chloroquine and its hydroxyl analogue to face bacterial, fungal and viral infections in the 21st century. Int J Antimicrob Agents. 2007;30(4):297-308. doi:10.1016/j.ijantimicag.2007.05.015

26. Zhang Y, Chen C, Zhu S, et al. Isolation of 2019-nCoV from a stool specimen of a laboratory-confirmed case of the coronavirus disease 2019 (COVID-19). CCDC Weekly. 2020;2 (8):123-124. doi:10.46234/ccdcw2020.033

27. Gao J, Tian Z, Yang X. Breakthrough: chloroquine phosphate has shown apparent efficacy in treatment of COVID-19 associated pneumonia in clinical studies. Biosci Trends. 2020;14(1):72-73. doi: $10.5582 /$ bst.2020.01047

28. Colson P, Rolain J-M, Raoult D. Chloroquine for the 2019 novel coronavirus. Int $J$ Antimicrob Agents. 2020;55(3):105923. doi:10.1016/j.ijantimicag.2020.105923

29. Zhu F-C, Li Y-H, Guan X-H, et al. Safety, tolerability, and immunogenicity of a recombinant adenovirus type-5 vectored COVID-19 vaccine: a dose-escalation, open-label, non-randomised, first-in-human trial. Lancet. 2020:395 (10240): 1845.

30. Wang F, Kream RM, Stefano GB. An Evidence Based Perspective on mRNA-SARS-CoV-2 Vaccine Development. Med Sci Monitor. 2020;26:e924700-e924700. doi:10.12659/MSM.924700

31. Smith TRF, Patel A, Ramos S, et al. Immunogenicity of a DNA vaccine candidate for COVID-19. Nat Commun. 2020;11 (1):2601. doi:10.1038/s41467-020-16505-0

32. World Health Organization. Coronavirus disease (COVID-19): Vaccines; 2020. Available from: https://www.who.int/news$\mathrm{room} / \mathrm{q}$-a-detail/coronavirus-disease-(covid-19)-vaccines.

33. Kasozi KI, Niedbała G, Alqarni $M$, et al. Bee Venom-A Potential Complementary Medicine Candidate for SARS-CoV-2 Infections. Front Public Health. 2020;8:755. doi:10.3389/ fpubh.2020.594458

34. Mahmood Z, Alrefai H, Hetta HF, et al. Investigating virological, immunological, and pathological avenues to identify potential targets for developing covid-19 treatment and prevention strategies. Vaccines. 2020;8(3):443. doi:10.3390/vaccines 8030443

35. Abd Ellah NH, Gad SF, Muhammad K, Hetta GEB. Nanomedicine as a promising approach for diagnosis, treatment and prophylaxis against COVID-19. Nanomedicine. 2020;15 (21):2085-2102. doi:10.2217/nnm-2020-0247 
36. Spencer JC, Ganguly R, Waldman RH. Nonspecific protection of mice against influenza virus infection by local or systemic immunization with Bacille Calmette-Guerin. J Infect Dis. 1977;136 (2):171-175.

37. Starr SE, Visintine AM, Tomeh MO, Nahmias AJ. Effects of immunostimulants on resistance of newborn mice to herpes simplex type 2 infection. Proc Soc Exp Biol Med. 1976;152 (1):57-60. doi:10.3181/00379727-152-39327

38. Wardhana DE, Sultana A, Mandang V, Jim E. The efficacy of Bacillus Calmette-Guerin vaccinations for the prevention of acute upper respiratory tract infection in the elderly. Acta Med Indones. 2011;43(3):185-190.

39. Nemes E, Geldenhuys H, Rozot V, et al. Prevention of M. tuberculosis infection with H4: IC31 vaccine or BCG revaccination. N Eng J Med. 2018;379(2):138-149. doi:10.1056/NEJMoa1714021

40. Ohrui T, Nakayama K, Fukushima T, Chiba H, Sasaki H. Prevention of elderly pneumonia by pneumococcal, influenza and BCG vaccinations. Nihon Ronen Igakkai Zasshi. 2005;42 (1):34-36. doi:10.3143/geriatrics.42.34

41. Stensballe LG, Nante E, Jensen IP, et al. Acute lower respiratory tract infections and respiratory syncytial virus in infants in Guinea-Bissau: a beneficial effect of BCG vaccination for girls community based case-control study. Vaccine. 2005;23 (10):1251-1257. doi:10.1016/j.vaccine.2004.09.006

42. Miller A, Reandelar MJ, Fasciglione K, Roumenova V, Li Y, Otazu GH. Correlation between universal BCG vaccination policy and reduced morbidity and mortality for COVID-19: an epidemiological study. MedRxiv. 2020.

43. Covián C, Retamal-Díaz A, Bueno SM, Kalergis AM. Could BCG vaccination induce protective trained immunity for SARS-CoV-2? Front Immunol. 2020;11:970. doi:10.3389/fimmu.2020.00970

44. Gursel M, Gursel I. Is global BCG vaccination-induced trained immunity relevant to the progression of SARS-CoV-2 pandemic? Allergy. 2020;69(1):1-4. doi:10.15036/arerugi.69.1

45. Weng C, Saal A, Butt WW, et al. Bacillus Calmette-Guérin vaccination and clinical characteristics and outcomes of COVID-19 in Rhode Island, United States: a cohort study. Epidemiol Infect. 2020;1-9.

46. Berg MK, Yu Q, Salvador CE, Melani I, Kitayama S. Mandated Bacillus Calmette-Guérin (BCG) vaccination predicts flattened curves for the spread of COVID-19. Medrxiv. 2020.

47. Pirouz B, Shaffiee Haghshenas S, Shaffiee Haghshenas S, Piro P. Investigating a serious challenge in the sustainable development process: analysis of confirmed cases of COVID-19 (new type of coronavirus) through a binary classification using artificial intelligence and regression analysis. Sustainability. 2020;12(6):2427. doi:10.3390/su12062427

48. Shaffiee Haghshenas S, Pirouz B, Shaffiee Haghshenas S, et al. Prioritizing and Analyzing the Role of Climate and Urban Parameters in the Confirmed Cases of COVID-19 Based on Artificial Intelligence Applications. Int J Environ Res Public Health. 2020;17(10):3730. doi:10.3390/ijerph17103730

49. World Health Organization. Bacille Calmette-Guérin (BCG) vaccination and COVID-19; 2020. Available from: https://www.who. $\mathrm{int} /$ news-room/commentaries/detail/bacille-calmette-guérin -(bcg)-vaccination-and-covid-19. Accessed March 3, 2021.

50. NBIC + . An overview of nanotechnology patents focusing on coronaviruses. NBIC + . Available from: https://statnano.com/ news/67513/An-Overview-of-Nanotechnology-Patents-Focusingon-Coronaviruses. Accessed March 3, 2021.

51. Poon LLM, Chu DKW, Chan KH, et al. Identification of a novel coronavirus in bats. J Virol. 2005;79(4):2001-2009. doi:10.1128/ JVI.79.4.2001-2009.2005

52. Livingston E, Bucher K, Rekito A. Coronavirus Disease 2019 and Influenza 2019-2020. JAMA. 2020;323(12):1122. doi:10.1001/ jama.2020.2633
53. Xu Z, Shi L, Wang Y, et al. Pathological findings of COVID-19 associated with acute respiratory distress syndrome. Lancet Respir Med. 2020;8(4):420-422. doi:10.1016/S2213-2600(20) 30076-X

54. Udugama B, Kadhiresan P, Kozlowski HN, et al. Diagnosing COVID-19: the Disease and Tools for Detection. ACS Nano. 2020;14(4):3822-3835. doi:10.1021/acsnano.0c02624

55. Zhou P, Yang X-L, Wang X-G, et al. A pneumonia outbreak associated with a new coronavirus of probable bat origin. Nature. 2020;579(7798):270-273. doi:10.1038/s41586-020-2012-7

56. Sahin AR, Erdogan A, Agaoglu PM, et al. 2019 novel coronavirus (COVID-19) outbreak: a review of the current literature. EJMO. 2020;4(1):1-7.

57. Goh GK-M, Dunker AK, Foster JA, Uversky VN. Rigidity of the Outer Shell Predicted by a Protein Intrinsic Disorder Model Sheds Light on the COVID-19 (Wuhan-2019-Ncov) Infectivity. Multidisciplinary Digital Publishing Institute; 2020.

58. Ahn D-G, Shin H-J, Kim M-H, et al. Current Status of Epidemiology, Diagnosis, Therapeutics, and Vaccines for Novel Coronavirus Disease 2019 (COVID-19). J Microbiol Biotechnol. 2020;30(3):313-324. doi:10.4014/jmb.2003.03011

59. Xiao F, Tang M, Zheng X, Liu Y, Li X, Shan H. Evidence for gastrointestinal infection of SARS-CoV-2. Gastroenterology. 2020;158(6):1831-1833. e1833. doi:10.1053/j.gastro.2020.02.055

60. Hindson J. COVID-19: faecal-oral transmission? Nat Rev Gastroenterol Hepatol. 2020;17(5):259. doi:10.1038/s41575-0200295-7

61. He F, Deng Y, Li W. Coronavirus disease 2019: what we know? J Med Virol. 2020;92(7):719-725. doi:10.1002/jmv.25766

62. Chen N, Zhou M, Dong X, et al. Epidemiological and clinical characteristics of 99 cases of 2019 novel coronavirus pneumonia in Wuhan, China: a descriptive study. Lancet. 2020;395 (10223):507-513.

63. Yang $\mathrm{X}, \mathrm{Yu} \mathrm{Y,} \mathrm{Xu} \mathrm{J,} \mathrm{et} \mathrm{al.} \mathrm{Clinical} \mathrm{course} \mathrm{and} \mathrm{outcomes} \mathrm{of}$ critically ill patients with SARS-CoV-2 pneumonia in Wuhan, China: a single-centered, retrospective, observational study. Lancet Respir Med. 2020;8(5):475-481. doi:10.1016/S22132600(20)30079-5

64. Magdy Beshbishy A, Hetta HF, Hussein DE, et al. Factors associated with increased morbidity and mortality of obese and overweight COVID-19 patients. Biology. 2020;9(9):280. doi:10.3390/ biology9090280

65. Li YC, Bai WZ, Hashikawa T. The neuroinvasive potential of SARS-CoV2 may play a role in the respiratory failure of COVID19 patients. J Med Virol. 2020;92(6):552-555. doi:10.1002/ jmv. 25728

66. Desforges M, Le Coupanec A, Dubeau P, et al. Human coronaviruses and other respiratory viruses: underestimated opportunistic pathogens of the central nervous system? Viruses. 2020;12 (1):14. doi:10.3390/v12010014

67. Sun T, Guan J. Novel coronavirus and the central nervous system. Mar. 2020:27(9):e52.

68. Petrosillo N, Viceconte G, Ergonul O, Ippolito G, Petersen E. COVID19, SARS and MERS: are they closely related? Clin Microbiol Infect. 2020;26(6):729-734. doi:10.1016/j.cmi.2020.03.026

69. Mahairas GG, Sabo PJ, Hickey MJ, Singh DC, Stover CK. Molecular analysis of genetic differences between Mycobacterium bovis BCG and virulent M. bovis. J Bacteriol. 1996;178(5):1274-1282. doi:10.1128/JB.178.5.1274-1282.1996

70. Edition TBWAn. A database of global BCG vaccination policies and practices; 2017. Available from: http://www.bcgatlas.org. Accessed March 3, 2021.

71. Zwerling A, Behr MA, Verma A, Brewer TF, Menzies D, Pai M. The BCG World Atlas: a database of global BCG vaccination policies and practices. PLoS Med. 2011;8(3):3. doi:10.1371/journal.pmed.1001012 
72. Aaby P, Roth A, Ravn H, et al. Randomized trial of BCG vaccination at birth to low-birth-weight children: beneficial nonspecific effects in the neonatal period? J Infect Dis. 2011;204 (2):245-252. doi:10.1093/infdis/jir240

73. Covián C, Fernández-Fierro A, Retamal-Díaz A, et al. BCGinduced cross-protection and development of trained immunity. Implication for vaccine design. Front Immunol. 2019;10:2806. doi:10.3389/fimmu.2019.02806

74. Arts RJ, Carvalho A, La Rocca C, et al. Immunometabolic pathways in BCG-induced trained immunity. Cell Rep. 2016;17 (10):2562-2571. doi:10.1016/j.celrep.2016.11.011

75. Ikeda S, Negishi T, Nishimura C. Enhancement of non-specific resistance to viral infection by muramyldipeptide and its analogs. Antiviral Res. 1985;5(4):207-215. doi:10.1016/0166-3542(85) 90025-7

76. Spencer JC, Ganguly R, Waldman RH. Nonspecific protection of mice against influenza virus infection by local or systemic immunization with Bacille Calmette-Guérin. J Infect Dis. 1977;136 (2):171-175. doi:10.1093/infdis/136.2.171

77. Moorlag S, Arts RJW, van Crevel R, Netea MG. Non-specific effects of BCG vaccine on viral infections. Clin Microbiol Infect. 2019;25(12):1473-1478. doi:10.1016/j.cmi.2019.04.020

78. Arts RJ, Moorlag SJ, Novakovic B, et al. BCG vaccination protects against experimental viral infection in humans through the induction of cytokines associated with trained immunity. Cell Host Microbe. 2018;23(1):89-100. e105.

79. Salem A, Nofal A, Hosny D. Treatment of common and plane warts in children with topical viable bacillus Calmette-Guerin. Pediatr Dermatol. 2013;30(1):60-63. doi:10.1111/j.15251470.2012.01848.x

80. Podder I, Bhattacharya S, Mishra V, et al. Immunotherapy in viral warts with intradermal Bacillus Calmette-Guerin vaccine versus intradermal tuberculin purified protein derivative: a double-blind, randomized controlled trial comparing effectiveness and safety in a tertiary care center in Eastern India. Indian J Dermatol Venereol Leprol. 2017;83(3):411.

81. Daulatabad D, Pandhi D, Singal A. BCG vaccine for immunotherapy in warts: is it really safe in a tuberculosis endemic area? Dermatol Ther. 2016;29(3):168-172. doi:10.1111/dth.12336

82. Leentjens J, Kox M, Stokman R, et al. BCG vaccination enhances the immunogenicity of subsequent influenza vaccination in healthy volunteers: a randomized, placebo-controlled pilot study. J Infect Dis. 2015;212(12):1930-1938. doi:10.1093/infdis/jiv332

83. Anderson FD, Ushijima RN, Larson CL. Recurrent herpes genitalis: treatment with Mycobacterium bovis (BCG). Obstet Gynecol. 1974;43(6):797-805.

84. Hippmann G, Wekkeli M, Rosenkranz AR, Jarisch R, Götz M. [Nonspecific immune stimulation with BCG in Herpes simplex recidivans. Follow-up 5 to 10 years after BCG vaccination]. Wien Klin Wochenschr. 1992;104(7):200-204. [Article in German].

85. Floc'h F, Werner G Increased resistance to virus infections of mice inoculated with BCG (Bacillus calmette-guérin). Paper presented at: Annales d'immunologie. 1976.

86. Mukherjee S, Subramaniam R, Chen H, Smith A, Keshava S, Shams H. Boosting efferocytosis in alveolar space using BCG vaccine to protect host against influenza pneumonia. PLoS One. 2017;12(7):7. doi:10.1371/journal.pone.0180143

87. de Bree LCJ, Marijnissen RJ, Kel JM, et al. Bacillus calmetteguérin-induced Trained immunity is not Protective for experimental influenza a/anhui/1/2013 (h7n9) infection in Mice. Front Immunol. 2018;9:869. doi:10.3389/fimmu.2018.00869

88. Scheid A, Borriello F, Pietrasanta C, et al. Adjuvant effect of Bacille Calmette-Guérin on hepatitis b vaccine immunogenicity in the preterm and term newborn. Front Immunol. 2018;9:29. doi:10.3389/fimmu.2018.00029
89. Kulkarni S, Mukherjee S, Pandey A, Dahake R, Padmanabhan U, Chowdhary AS. Bacillus Calmette-Guérin Confers Neuroprotection in a Murine Model of Japanese Encephalitis. Neuroimmunomodulation. 2016;23(5-6):278-286. doi:10.1159/ 000452171

90. Lodmell DL, Ewalt LC. Enhanced resistance against encephalomyocarditis virus infection in mice, induced by a nonviable Mycobacterium tuberculosis oil-droplet vaccine. Infect Immun. 1978;19(1):225-230. doi:10.1128/IAI.19.1.225-230.1978

91. Lodmell DL, Ewalt LC. Induction of enhanced resistance against encephalomyocarditis virus infection of mice by nonviable Mycobacterium tuberculosis: mechanisms of protection. Infect Immun. 1978;22(3):740-745. doi:10.1128/IAI.22.3.740-745.1978

92. Suenaga T, Okuyama T, Yoshida I, Azuma M. Effect of Mycobacterium tuberculosis BCG infection on the resistance of mice to ectromelia virus infection: participation of interferon in enhanced resistance. Infect Immun. 1978;20(1):312-314. doi:10.1128/IAI.20.1.312-314.1978

93. Sakuma T, Suenaga T, Yoshida I, Azuma M. Mechanisms of enhanced resistance of Mycobacterium bovis BCG-treated mice to ectromelia virus infection. Infect Immun. 1983;42(2):567-573. doi:10.1128/IAI.42.2.567-573.1983

94. Mathurin KS, Martens GW, Kornfeld H, Welsh RM. CD4 T-cellmediated heterologous immunity between mycobacteria and poxviruses. J Virol. 2009;83(8):3528-3539. doi:10.1128/ JVI.02393-08

95. Pulendran B, Ahmed R. Immunological mechanisms of vaccination. Nat Immunol. 2011;12(6):509. doi:10.1038/ni.2039

96. Kumar S, Sunagar R, Gosselin E. Bacterial protein toll-likereceptor agonists: a novel perspective on vaccine adjuvants. Front Immunol. 2019;10:1144. doi:10.3389/fimmu.2019.01144

97. Moliva JI, Turner J, Torrelles JB. Immune responses to bacillus Calmette-Guérin vaccination: why do they fail to protect against Mycobacterium tuberculosis? Front Immunol. 2017;8:407.

98. Dockrell HM, Smith SG. What have we learnt about BCG vaccination in the last 20 years? Front Immunol. 2017;8:1134. doi:10.3389/fimmu.2017.01134

99. Gagliardi MC, Teloni R, Giannoni F, et al. Mycobacterium bovis Bacillus Calmette-Guérin infects DC-SIGN-dendritic cell and causes the inhibition of IL-12 and the enhancement of IL-10 production. J Leukoc Biol. 2005;78(1):106-113. doi:10.1189/jlb.0105037

100. Tsuji S, Matsumoto M, Takeuchi O, et al. Maturation of human dendritic cells by cell wall skeleton of Mycobacterium bovis bacillus Calmette-Guerin: involvement of toll-like receptors. Infect Immun. 2000;68(12):6883-6890. doi:10.1128/ IAI.68.12.6883-6890.2000

101. Joosten SA, van Meijgaarden KE, Arend SM, et al. Mycobacterial growth inhibition is associated with trained innate immunity. $J$ Clin Invest. 2018;128(5):1837-1851. doi:10.1172/JCI97508

102. Kaufmann SH Tuberculosis vaccines: time to think about the next generation. Paper presented at: Seminars in immunology. 2013.

103. Bertholet S, Ireton GC, Kahn M, et al. Identification of human $\mathrm{T}$ cell antigens for the development of vaccines against Mycobacterium tuberculosis. J Immunol. 2008;181 (11):7948-7957. doi:10.4049/jimmunol.181.11.7948

104. Hanekom WA. The immune response to BCG vaccination of newborns. Ann N Y Acad Sci. 2005;1062(1):69-78. doi:10.1196/ annals. 1358.010

105. Soares AP, Kwong Chung CK, Choice T, et al. Longitudinal changes in $\mathrm{CD} 4(+)$ T-cell memory responses induced by BCG vaccination of newborns. J Infect Dis. 2013;207(7):1084-1094. doi:10.1093/infdis/jis941

106. Morel C, Badell E, Abadie V, et al. Mycobacterium bovis BCG-infected neutrophils and dendritic cells cooperate to induce specific T cell responses in humans and mice. Eur $J$ Immunol. 2008;38(2):437-447. doi:10.1002/eji.200737905 
107. Silva CL, Bonato VL, Lima VM, Faccioli LH, Leão SC. Characterization of the memory/activated $\mathrm{T}$ cells that mediate the long-lived host response against tuberculosis after bacillus Calmette-Guérin or DNA vaccination. Immunology. 1999;97 (4):573-581. doi:10.1046/j.1365-2567.1999.00840.x

108. Kleinnijenhuis J, Quintin J, Preijers F, et al. Bacille Calmette-Guerin induces NOD2-dependent nonspecific protection from reinfection via epigenetic reprogramming of monocytes. Proc Nat Acad Sci. 2012;109(43):17537-17542. doi:10.1073/ pnas. 1202870109

109. Kleinnijenhuis J, van Crevel R, Netea MG. Trained immunity: consequences for the heterologous effects of BCG vaccination. Trans R Soc Trop Med Hyg. 2015;109(1):29-35. doi:10.1093/trstmh/tru168

110. Netea MG, Joosten LA, Latz E, et al. Trained immunity: a program of innate immune memory in health and disease. Science. 2016;352(6284):6284. doi:10.1126/science.aaf1098

111. Kakodkar P, Kaka N, Baig M. A comprehensive literature review on the clinical presentation, and management of the pandemic coronavirus disease 2019 (COVID-19). Cureus. 2020;12:4.

112. Gallagher J, Watson C, Ledwidge M. Association of Bacille Calmette-Guérin (BCG), adult pneumococcal and adult seasonal influenza vaccines with covid-19 adjusted mortality rates in level 4 European countries. medRxiv. 2020.

113. Hegarty PK, Sfakianos JP, Giannarini G, DiNardo AR, Kamat AM. COVID-19 and Bacillus Calmette-Guérin: what is the link? Eur Urol Oncol. 2020;3(3):259-261. doi:10.1016/j.euo.2020.04.001

114. Akiyama Y, Ishida T. Relationship between COVID-19 death toll doubling time and national BCG vaccination policy. medRxiv. 2020.

115. Dayal D, Gupta S. Connecting BCG vaccination and COVID-19: additional data. Medrxiv. 2020.

116. Kuratani N. Association of national Bacille Calmette-Guérin vaccination policy with COVID-19 epidemiology: an ecological study in 78 countries. medRxiv. 2020.

117. Tomita Y, Sato R, Ikeda T, Sakagami T. BCG vaccine may generate cross-reactive $\mathrm{T}$ cells against SARS-CoV-2: in silico analyses and a hypothesis. Vaccine. 2020;38(41):6352-6356. doi:10.1016/j.vaccine.2020.08.045

118. Freyne B, Donath S, Germano S, et al. Neonatal BCG vaccination influences cytokine responses to toll-like receptor ligands and heterologous antigens. J Infect Dis. 2018;217(11):1798-1808. doi:10.1093/infdis/jiy069

119. Weng C, Saal A, Butt WW, et al. Bacillus Calmetteâ€"GuÃ@rin vaccination and clinical characteristics and outcomes of COVID19 in Rhode Island, United States: a cohort study. Epidemiol Infect. 2020;148.

120. Green CM, Fanucchi S, Fok ET, et al. COVID-19: a model correlating BCG vaccination to protection from mortality implicates trained immunity. MedRxiv. 2020.

121. Klinger D, Blass I, Rappoport N, Linial M. Significantly improved COVID-19 outcomes in countries with higher BCG vaccination coverage: a multivariable analysis. medRxiv. 2020.

122. Sharma AR, Batra G, Kumar M, et al. BCG as a game-changer to prevent the infection and severity of COVID-19 pandemic? Allergologia et Immunopathologia (Mard). Sep-Oct. 2020;48 (5):507-517.
123. Ebina-Shibuya R, Horita N, Namkoong H, Kaneko T. National policies for paediatric universal BCG vaccination were associated with decreased mortality due to COVID -19 . Respirology. 2020;25(8):898-899. doi:10.1111/resp.13885

124. Kinoshita $M$, Tanaka M. Impact of routine infant $B C G$ vaccination on COVID-19. J Infect. 2020;81(4):625-633. doi:10.1016/j. jinf.2020.08.013

125. Sharma A, Sharma SK, Shi Y, et al. BCG vaccination policy and preventive chloroquine usage: do they have an impact on COVID-19 pandemic? Cell Death Dis. 2020;11(7):1-10. doi:10.1038/s41419-020-2720-9

126. Urashima M, Otani K, Hasegawa Y, Akutsu T, Vaccination BCG. Mortality of COVID-19 across 173 Countries: an Ecological Study. Int $J$ Environ Res Public Health. 2020;17:15. doi:10.3390/ijerph17155589

127. Miyasaka M. Is BCG vaccination causally related to reduced COVID-19 mortality? EMBO Mol Med. 2020;12(6):e12661. doi:10.15252/emmm.202012661

128. Sanchez-Mostiero D, Melicor AF. Should Bacillus CalmetteGuérin (BCG) vaccine be used in the prophylaxis of COVID19? ActaMedica Philippina. 2020;54(Special Issue on Coronavirus Disease (COVID19)).

129. O'Connor E, Teh J, Kamat AM, Lawrentschuk N. Bacillus Calmette Guérin (BCG) vaccination use in the fight against COVID-19-what's old is new again? Future Med. 2020.

130. De Vrieze J. Can a century-old TB vaccine steel the immune system against the new coronavirus. Science. 2020;370 (6519):895-897. doi:10.1126/science.370.6519.895

131. Hollm-Delgado M-G, Stuart EA, Black RE. Acute lower respiratory infection among Bacille Calmette-Guérin (BCG)-vaccinated children. Pediatrics. 2014;133(1):e73-e81. doi:10.1542/ peds.2013-2218

132. Hamiel U, Kozer E, Youngster I. SARS-CoV-2 Rates in BCG-Vaccinated and Unvaccinated Young Adults. JAMA. 2020;323(22):2340. doi:10.1001/jama.2020.8189

133. Faust L, Huddart S, MacLean E, Svadzian A. Universal BCG vaccination and protection against COVID-19: critique of an ecological study. J Club. 2020;1.

134. Pollard AJ, Finn A, Curtis N. Non-specific effects of vaccines: plausible and potentially important, but implications uncertain. Arch Dis Child. 2017;102(11):1077-1081. doi:10.1136/archdischild-2015-310282

135. Arts RJW, Moorlag SJCFM, Novakovic B, et al. BCG vaccination protects against experimental viral infection in humans through the induction of cytokines associated with trained immunity. Cell Host Microbe. 2018;23(1):89-100.e105. doi:10.1016/j.chom.2017.12.010

136. Singh BR, Gandharva R. Are BCG vaccination, population density, median age and poverty important determinants of COVID-19 pandemic spread, morbidity and mortality? Morbidity Mortality. 2020;10.
Infection and Drug Resistance

\section{Publish your work in this journal}

Infection and Drug Resistance is an international, peer-reviewed openaccess journal that focuses on the optimal treatment of infection (bacterial, fungal and viral) and the development and institution of preventive strategies to minimize the development and spread of resistance. The journal is specifically concerned with the epidemiology of antibiotic resistance and the mechanisms of resistance development and diffusion in both hospitals and the community. The manuscript management system is completely online and includes a very quick and fair peerreview system, which is all easy to use. Visit http://www.dovepress.com/ testimonials.php to read real quotes from published authors. 